\title{
A Love Triangle Between God, Sophia, and the Righteous Interwoven in the Retelling of the Pentateuchal Stories in Wisdom 10
}

\author{
Ananda B. Geyser-Fouché \\ https://orcid.org/0000-0002-8898-4272 \\ University of Pretoria, South Africa \\ ananda@up.ac.za
}

\section{Abstract}

In the Wisdom of Solomon, with special reference to chapters 6 to 10 , wisdom is personified as a woman. This image is quite often found, especially in the wisdom literature. In the Wisdom of Solomon, Sophia is portrayed as a person who can speak, act, and feel, but most of all someone who can be loved and desired. She is portrayed as someone that is loved alternately by God and by the righteous. In Wisdom 10 Sophia is interwoven in the retelling of the Pentateuchal stories. She is the reason the righteous forefathers made the correct decisions, she protected and preserved them and gave them power, while the unrighteous are portrayed as leaving her and consequently making the wrong decisions. It is also interesting to notice the development in the concept of both wisdom and retribution from the traditional perspectives.

Keywords: Wisdom of Solomon; Sophia; Wisdom; retribution

\section{UNISA}

Journal for Semitics

https://upjournals.co.za/index.php/JSEM

Volume 30 | Number 2 | 2021 | \#9217| 15 pages https://doi.org/10.25159/2663-6573/9217

ISSN 2663-6573 (Online), ISSN 11013-8471 (Print)

(C) The Author(s) 2022 


\section{Introduction $^{1}$}

The Wisdom of Solomon originated probably between the first century BCE and $40 \mathrm{CE}$ (at the end of the Ptolemaic period to the early period of the Roman rule of Egypt) in Egyptian Alexandria and was influenced by Hellenistic literary forms. Concerning the background of the author, he was possibly a scribe or a sage with expert knowledge of both Israelite traditions and Hellenistic rhetoric. The Hellenistic context and rhetoric are evident in the book, for the author has a bold approach towards Hellenism (Perdue 2008, 292-93). The recipients were most likely young Jewish people and the book was written at a time when the Israelite religion competed with the Isis cult in the Egyptian communities (Baumann 2014, 71-72). Baumann proposes that this book might be an endeavour to convert people back to Judaism, therefore the portrayal of Lady Wisdom in a similar image as Isis (Baumann 2014, 72).

The Wisdom of Solomon consists of 19 chapters that are generally divided into three parts: 1-6:21 is seen as "the book of eschatology," 6:22-10:21 is seen as the "book of wisdom," and the last unit of chapters is seen as the "book of history" (Collins 1997, 179). In the Wisdom of Solomon, with special reference to chapters 6 to 10, wisdom is personified as a woman and this notion is quite often found especially in the wisdom literature.

Baumann (2014, 57-58) says that personified wisdom appears in three Old Testament writings, namely Proverbs 1-9, in Sirach (Ecclesiasticus), and the Wisdom of Solomon. Wisdom is portrayed in these texts as a person who can speak and act. Because the word for wisdom is feminine in both Hebrew and Greek and because of the feminine personification of Wisdom, she is often called "Lady Wisdom." Baumann $(2014,57)$ says:

The expansion of an earlier image of God, dominated by masculine aspects, to include the missing feminine side may help account for this feminine portrayal of Wisdom. Personified Wisdom appears in different social and literary contexts and can be viewed as one of the most fascinating literary creations of the Bible, especially in relation to the question of a feminine image of God.

In the Wisdom of Solomon, Sophia is portrayed as a person who can speak, act, and feel, but most of all someone who can be loved and desired. She is portrayed as someone that is loved alternately by God and by the righteous. In Wisdom 10, Sophia is interwoven in the retelling of the Pentateuchal narratives. She is the reason the righteous

1 This article is a reworked version of a part of a $\mathrm{PhD}$ (Semitic Languages) thesis, which was completed under the supervision of Prof. G. T. M. Prinsloo in the Department of Ancient and Modern Languages and Cultures at the Faculty of Humanities, University of Pretoria, with the title "The Ideological Necessity for the Transformation of the Lady Metaphors in Judaic Wisdom Literature." 
forefathers had made the correct decisions. She preserved the righteous and gave them power, while the unrighteous are portrayed as forsaking her, which led to bad decisions.

In this article, I focus on several interesting aspects in this text. ${ }^{2}$ These aspects will be dealt with in three parts. The first part is concerned with the relational aspect in the portrayal of wisdom as a woman. Zimmerman $(2008,243)$ correctly notices that there is a love triangle between God, Sophia, and the righteous. With regard to the relational discussion, I will examine the relationship between the three parties, which includes the roles and position(s) in this relationship, the portrayal of Sophia, as well as the actions and/or reactions that are linked to this relationship. The second aspect that will be discussed is how this intertwined relationship is utilised to retell the Pentateuchal narratives in Wisdom 10. The third part will be a summarised overview of the development of the concept of both wisdom and retribution from the traditional perspectives.

\section{Relationship —A Love Triangle}

The Wisdom of Solomon starts by saying in 1:6 that Wisdom is a kindly spirit. In chapters 6:12-11:4, an intertwined love relationship is described in the form of a love triangle. On the one hand, there is the love between God and the righteous, and on the other hand, there is the love between God and Sophia but also the love between the righteous and Sophia. I will list the specific verses in which this love is expressed below and will discuss them after the listing.

\section{The Relationship Between God and Sophia}

The relationship between God and Sophia is evident. She is the mother of all the good things (7:12), the breath of the power of God, and an emanation of the pure glory of the Almighty (7:25); she is the reflection of eternal light and a spotless mirror of the activity of God and an image of his goodness (7:26), and although she is one, she can do all things, and while remaining in herself, she renews all things, and in every generation she passes into holy souls and makes them friends of God and prophets (7:27). She reaches with might from one end of the world to the other and orders all things well (8:1), she glorifies her noble birth by having a shared life with $\mathrm{God},{ }^{3}$ and the Sovereign Lord of all loves her (8:3), for she is an initiate in the knowledge of God and chooses his works (8:4) and if understanding is productive, who more than she is the fashioner of the things that exist (8:6)?

2 This study will focus on an overview of the whole corpus in which wisdom is personified (Wis 6-10) but for the discussion on the retelling of the history, the focus will be on Chapter 10. All references to the text are from Rahlfs's LXX text (Rahlfs 2006, 1096-1104); reference to the translation is the LXX NETS translation of Knibb (2007).

$3 \sigma \nu \mu \beta i ́ \omega \sigma v v \theta \varepsilon 0 \tilde{v}$ - she can be seen as conversant with God. 


\section{The Relationship Between Sophia and the Righteous}

A relationship between Sophia and the righteous is also described. She is easily discerned by those that love her, and found by those that seek her (6:12); concern for instruction is love of her, and love of her is keeping her laws, and paying attention to her laws is confirmation of incorruption (6:12); the desire for wisdom leads to a kingdom (6:20); the righteous preferred her (7:8) and loved her more than health and beauty, and chose to have her $(7: 10)$. The righteous loved her ... sought her ... sought to take her as a bride ... became enamoured of her beauty $(8: 2) .{ }^{4}$ If one loves righteousness, ${ }^{5}$ the fruits of her labours are virtues ... (8:7). The pious was determined to take her to live with him, knowing that she would be a good counsellor for him and a comfort in cares and grief (8:9). She will give rest to the pious when he enters his house, because companionship with her has no bitterness, and living with her no grief, rather gladness and joy (8:16). In friendship with her, he finds pure delight and in the labours of her hands, unfailing wealth and in training in intimate companionship with her understanding and great renown in conversing with her, he went about seeking how he might take her to himself (8:18). He will only be able to have her if God gives her as a gift $(8: 21){ }^{6}$

\section{The Relationship Between God and the Righteous}

It is possible for the righteous to come near to God-incorruption brings one near to God (6:19). He tells that he prayed and called upon God (7:1). Friendship with God is possible through Sophia $(7: 14)$ and God loves nothing except the person who lives with wisdom (7:28) and, according to 11:4, they called upon Him.

It is interesting to notice that there is a definite love triangle, where God can be loved by both the righteous and Sophia; God loves Sophia and she can be loved by the righteous, but the subordination of the righteous in relation to God and Sophia is clear. God loves the persons who live with wisdom. Sophia is the mediator between God and the righteous. Her role as mediator is clearly expressed in Wis 7:27: Although she is one, she can do all things, and while remaining in herself, she renews all things, and in every generation she passes into holy souls and makes them friends of God and prophets. Wisdom 7:14 states that through her one can obtain friendship with God. Although the relationship between Sophia and the righteous is sometimes erotically portrayed (especially in Wis 8), Sophia is exalted above the righteous. Most of the time she is portrayed as the mediator between God and the righteous. She is portrayed alternately as a little bit less than God, but sometimes also as equal. The relationship

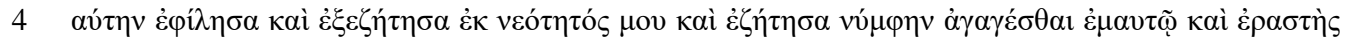

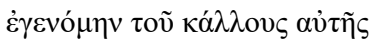

It is noticeable that both $\phi 1 \lambda \dot{\varepsilon} \omega$ and $\tilde{\varepsilon} \rho \circ \zeta$ are used here to describe the love that the righteous has for Sophia.

5 In this verse "righteousness" seems to be a synonym for wisdom.

6 This idea of Sophia being a gift from God is highlighted in Wis 7:7; 8:4, 21, 9:4, 17. 
can therefore be called a love triangle, but the participants are not on equal footing. The process of interrelatedness is explained in Wis 6:17-19:

${ }^{17}$ For her true beginning is desire for instruction, ${ }^{18}$ and concern for instruction is love of her, and love of her, is keeping her laws, and paying attention to her laws is confirmation of incorrupt, ${ }^{19}$ and incorruption brings one near to God.

\section{Portrayal of Sophia}

Sophia is portrayed as radiant and unfading (Wis 6:12), she cannot be compared to any gems, gold, or silver (7:9), she is more attractive than the sun or any constellation, even more radiant than light (Wis 7:29). She has a spirit that is intelligent, holy, unique, of many parts, subtle, free-moving, lucid, unpolluted, distinct, invulnerable, loving the good, sharp, unhindered, beneficent, loving towards humanity, firm, unfailing, free from care, all-powerful, all-surveying and penetrating all spirits that are intelligent, pure, most subtle (Wis 7:22-23). She is portrayed as the mother of all good things (Wis 7:11$12)$, the breath of the power of God and an emanation of the Almighty's glory (7:25), she reflects eternal light and is a spotless mirror of the activity of God; an image of his goodness (7:26); God's co-creator (Wis 8:4; 9:97); God loves her and shares a life with her $(8: 3)$. She is a wife and lover for the righteous (Wis 8:2,16). She can be desired $(6: 13 ; 8: 2)$ loved $(6: 12,18 ; 8: 2)$ and sought $(6: 12 ; 8: 2)$. She is most skilful in everything she does (8:6), a celestial being who is sitting next to God's throne (9:4); she saves humans through her guidance $(9: 18)$ and protects humans $(10: 1)$ and acts like a feminine deity $(10: 1-11: 1)$.

\section{She was there before creation and sitting next to God on his throne- 9:1-4, 9-11}

1 "God of the fathers and Lord of mercy, who made all things by your word

2 and by your wisdom formed human beings to rule over the creatures that were made by you

${ }^{3}$ and to manage the world in holiness and righteousness and to pronounce judgment in uprightness of soul,

${ }^{4}$ give me wisdom that sits by you on your throne, and do not reject me from amongst your children,

${ }^{9}$ With you is wisdom, which knows your works and was present when you made the world and understands what is pleasing in your eyes and what is right according to your commandments.

${ }^{10}$ Send her out from the holy heavens, and from your glorious throne send her, that, being present with me, she may labor with me and that I may learn what is well-pleasing before you,

${ }^{11}$ for she knows all things and understands them and will guide me prudently in my actions and guard me with her glory. 


\section{She is eternal}

6:12-Wisdom is radiant and unfading

$7: 10$ - the radiance from her never rests

$7: 14$ - an unfailing treasure

$7: 26$ - she is the reflection of eternal light

7:27 - she renews all things, and in every generation, she passes into holy souls and makes them friends of God and prophets.

Sophia is portrayed alternately as both the consort of God and the consort of the righteous; in some verses she appears somewhat human but most of the times she seems to be the feminine deity. Although Wisdom 8 refers to her in erotic terminology, she is still more associated with spirit and light than being human. Sophia and God switch roles from time to time - then she is the creator, then he is, sometimes she is the guidance and protector and at other times he is. At times she is portrayed as his consort and other times almost his equal. She is guiding the righteous in the same way that God does, which links very strongly with Proverbs 8 (verses 17, 22-36). Römer $(2013,3)$ explains that when monotheism (monolatrism) became pertinent in Judaism (Persian period) the image and identity of the female deity had to be concealed in abstract concepts like wisdom, which explains why wisdom is so often personified.

\section{Actions/Reactions Created by this Relationship}

In the love triangle between God, Sophia, and the righteous there are actions from the side of the righteous which lead him to Sophia and reconcile him with God. There are also reactions from him because of her. Part of these actions/reactions is the value of being in this relationship or the price of not being in this relationship.

These actions and/or reactions will not be discussed in detail, but they include desire, seek, love, to prefer her, to cling unto her, to fix one's thoughts on her, to honour her, to converse with her, to possess her, and to receive her (see Wis 6:12, 13, 15, 20, 21; 7:7-8, 10; 8:2, 8-9, 16, 18, 21; see also Geyser-Fouché 2019, 350-51). Most interesting is the emphasis that a person can only pray to obtain wisdom, it cannot be gained by doing something. Sophia is portrayed as a gift that can be prayed for (see Wis $7: 7 ; 8: 4$, $21 ; 9: 4,17)$.

The value of having a relationship with her or the price for not having one is most of the time linked to immortality. I will list a few of them below.

She provides virtues, self-control, righteousness, courage, delight, wealth, understanding and renown (Wis 8:7,18):

7 ... the fruits of her labors are virtues, for she teaches self-control and understanding, righteousness and courage; nothing is more useful in life than these for human beings. 
$18 \ldots$ in friendship with her pure delight and in the labors of her hands unfailing wealth and in training in intimate companionship with her understanding and great renown in conversing with her...

Because of her the righteous will have glory, honour, good judgement, and be admired (Wis 8:10-12, 14-15):

${ }^{10}$ Because of her, I will have glory among the multitudes and honor in the presence of elders, although I am young.

${ }^{11}$ I will be found quick in judgment and in the sight of rulers will be admired.

${ }^{12}$ When I am silent, they will wait, and when I speak, they will pay attention, and if I talk at greater length, they will place a hand on their mouth.

${ }^{14}$ I will govern peoples, and nations will be subject to me;

15 dread princes will fear me when they hear of me; among the multitude I will show myself noble, and in war courageous.

Immortality is centred between these verses above (Wis 8:13), which might be for emphatic reasons. This concept is repeated in verse 17:

${ }^{13}$ Because of her, I will have immortality and will leave behind an everlasting memorial for those who come after me.

${ }^{17}$ When I considered these things in myself and pondered in my heart that in kinship with wisdom is immortality

Through Sophia, God appointed the righteous to rule over his creatures and to manage the world (Wis 9:2-3):

2 and by your wisdom formed human beings to rule over the creatures that were made by you

${ }^{3}$ and to manage the world in holiness and righteousness and to pronounce judgment in uprightness of soul,

She is the one that guides the righteous into understanding what conduct is correct and pleasing to God (Wis 9:10-18):

${ }^{10}$ Send her out from the holy heavens, and from your glorious throne send her, that, being present with me, she may labor with me and that I may learn what is well-pleasing before you,

${ }^{11}$ for she knows all things and understands them and will guide me prudently in my actions and guard me with her glory.

12 Then my deeds will be acceptable, and I will judge your people justly and be worthy of the throne of my father.

${ }^{13}$ For what human being can learn divine counsel? Or who can conceive what the Lord wills?

${ }^{14}$ For the thoughts of mortals are worthless, and our inventions liable to fail. 
${ }^{15}$ For a corruptible body burdens the soul, and the earthly tent weighs down a mind full of cares.

${ }^{16}$ With difficulty we make inferences about what is on earth, and what is at hand we find with labor, but who has traced out what is in the heavens?

${ }^{17}$ Who has learned your counsel unless you gave wisdom and sent your holy spirit from on high?

${ }^{18}$ And thus the ways of those on earth were set right, and human beings were taught what is pleasing to you and were saved by wisdom.

The value of having a relationship with Sophia (as well as the price of not having one) is the core of Wisdom 10. Because this chapter will be discussed in the next section the specific verses which are applicable will not be mentioned here.

\section{The Love-Triangle is used to Retell the Pentateuchal Narratives in Wisdom 10}

The study on the relationship between God, Sophia, and the righteous has shown that Sophia is seen in the Wisdom of Solomon as some kind of feminine deity who acts as the mediator between God and the righteous. This section will focus on this relationship and how it is utilised to retell the Pentateuchal narratives. For the sake of discussion, this text will be listed below. Because this text is transitional, ${ }^{8}$ the first verses of Chapter 11 will also be listed.

\begin{tabular}{|c|c|c|}
\hline \multicolumn{3}{|c|}{ Wisdom 10:1-219 } \\
\hline $\mathbf{L X X}^{10}$ & $\begin{array}{l}\text { LXX NETS-Translation (Knibb } \\
\text { 2007, 705-706) }\end{array}$ & $\begin{array}{l}\text { Pentateuchal } \\
\text { Narrative }\end{array}$ \\
\hline 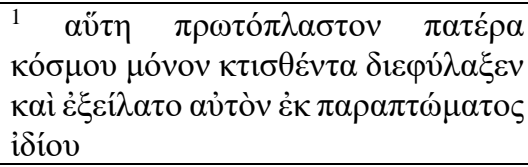 & $\begin{array}{l}\text { She carefully guarded the first- } \\
\text { formed father of the world, when he } \\
\text { alone was created, and delivered } \\
\text { him from his own transgression; }\end{array}$ & \multirow[t]{2}{*}{ Adam } \\
\hline 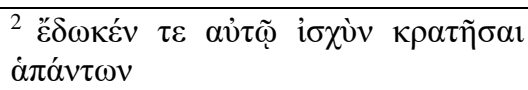 & $\begin{array}{l}{ }^{2} \text { she gave him strength to rule over } \\
\text { all things. }\end{array}$ & \\
\hline
\end{tabular}

8 The book of Wisdom consists of 19 chapters. The first 6 chapters focus on wisdom's gift of immortality, with chapter 6 being transitional. The centre part (Wis 6:22 to 11:1) is a eulogy of wisdom, with chapter 10-11:1 as a transitional chapter. The last part (Wis 11:2-19) is concerned with the exodus narrative and divine wisdom and justice (cf. Baumann 2014; Webster 1998; Winston 1979; Bosman 2012).

9 In the text, the value of having a relationship with Sophia is highlighted in grey and the price of abandoning her and/or not following her is underlined. The Pentateuchal narrative and/or persons who are referred to in the text, is indicated in the last column.

10 Rahlfs $(2006,1103-4)$. 


\begin{tabular}{|c|c|c|}
\hline 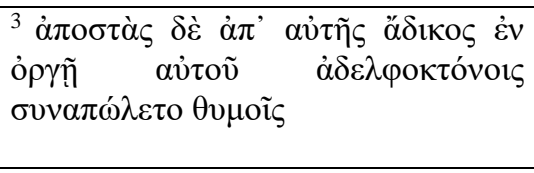 & $\begin{array}{l}3 \text { But when an unrighteous man } \\
\text { departed from her in his anger, he } \\
\text { perished through his }{ }^{11} \text { fratricidal } \\
\text { rage. }\end{array}$ & Cain \\
\hline 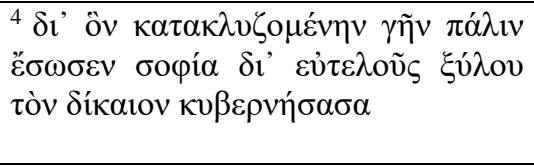 & $\begin{array}{l}4 \text { When because of him the earth } \\
\text { was flooded, wisdom again saved it, } \\
\text { piloting the righteous man by a } \\
\text { worthless piece of wood. }\end{array}$ & Noah \\
\hline \multirow{2}{*}{ 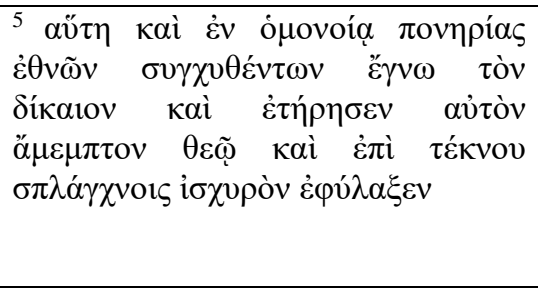 } & \multirow{2}{*}{$\begin{array}{l}5 \text { She also, when nations, } \\
\text { collaborating together in } \\
\text { wickedness, were put to confusion, } \\
\text { recognized the righteous man and } \\
\text { preserved him blameless with God } \\
\text { and kept him strong in the face of } \\
\text { compassion for his child. }\end{array}$} & Babel \\
\hline & & Abraham \\
\hline 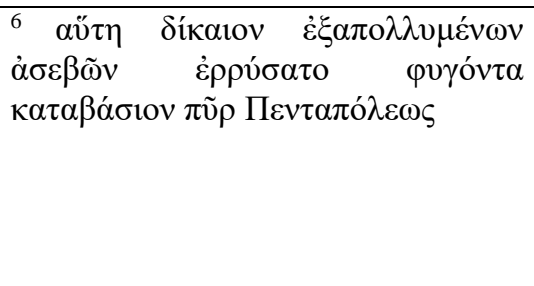 & $\begin{array}{l}6 \text { She rescued a righteous man, } \\
\text { when the impious were perishing, } \\
\text { as he fled from the fire descending } \\
\text { on the Five Cities. }\end{array}$ & $\begin{array}{l}\text { Lot } \\
\text { Sodom, } \\
\text { Gomorrah, } \\
\text { Admah, } \\
\text { Zeboïm, }\end{array}$ \\
\hline \multirow{2}{*}{ 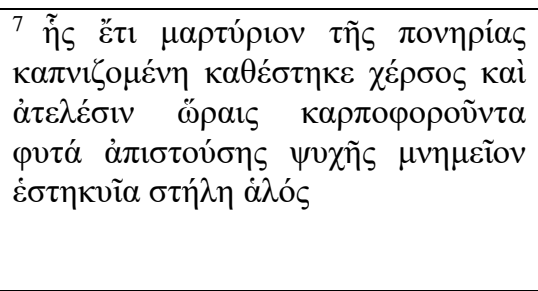 } & \multirow{2}{*}{$\begin{array}{l}7 \text { As testimony of their evil a } \\
\text { smoking waste still remains, and } \\
\text { plants bearing fruit that does not } \\
\text { ripen, }{ }^{12} \\
\text { and }^{13} \text { a stele of salt standing as a } \\
\text { monument to an unbelieving soul. }\end{array}$} & $\begin{array}{c}\text { Bela/Loar } \\
\text { (Gen 14:1-3) }\end{array}$ \\
\hline & & Lot's wife \\
\hline 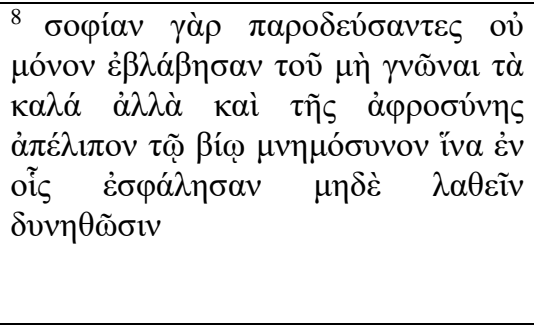 & $\begin{array}{l}{ }^{8} \text { For, having passed wisdom by, } \\
\text { they not only were hindered from } \\
\text { recognizing the things that are } \\
\text { good, but also left behind for human } \\
\text { life a reminder of their folly in order } \\
\text { that in the things in which they } \\
\text { failed they would not be able to } \\
\text { escape detection. }\end{array}$ & \\
\hline 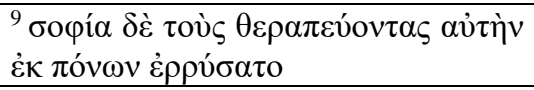 & $\begin{array}{l}{ }^{9} \text { But wisdom rescued from troubles } \\
\text { those who served her. }\end{array}$ & \\
\hline
\end{tabular}

11 Footnote from translator: "his" is "Lacking in Gk."

12 Footnote from translator: "that does not ripen" can also be "before it is ripe."

13 Footnote from translator: "and" is "Lacking in Gk." 


\begin{tabular}{|c|c|c|}
\hline 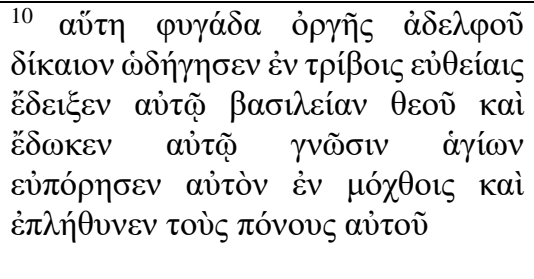 & $\begin{array}{l}{ }^{10} \text { When a righteous man fled from } \\
\text { his brother's anger, she guided him } \\
\text { on straight paths; she showed him a } \\
\text { divine kingdom and gave him } \\
\text { knowledge of holy things; she } \\
\text { prospered him in his toils and } \\
\text { increased the fruits of his labor. }\end{array}$ & \multirow{3}{*}{ Jacob } \\
\hline 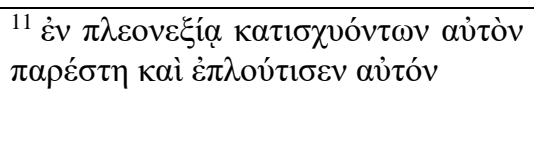 & $\begin{array}{l}{ }^{11} \text { When in their greed men were } \\
\text { trying to prevail over him, she stood } \\
\text { by him and made him rich; }\end{array}$ & \\
\hline 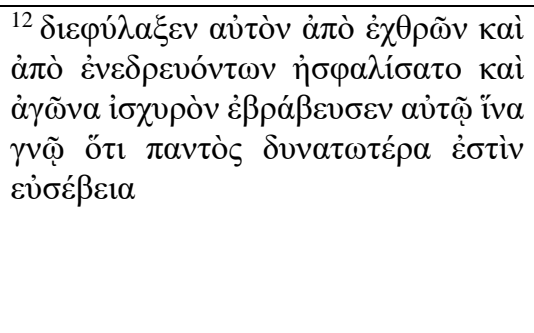 & $\begin{array}{l}12 \text { she carefully guarded him from } \\
\text { his enemies, and from those who } \\
\text { lay in wait for him she kept him } \\
\text { safe; and in his arduous contest she } \\
\text { decided in } \\
\text { his favor, that he might learn that } \\
\text { piety is more powerful than } \\
\text { everything. }\end{array}$ & \\
\hline 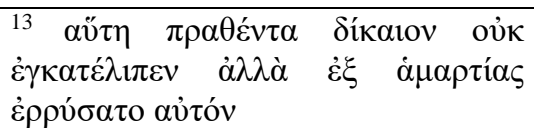 & $\begin{array}{l}{ }^{13} \text { She did not abandon a righteous } \\
\text { man who had been sold but rescued } \\
\text { him from sin; }\end{array}$ & \multirow{3}{*}{$\begin{array}{l}\text { Joseph } \\
\text { Egypt }\end{array}$} \\
\hline 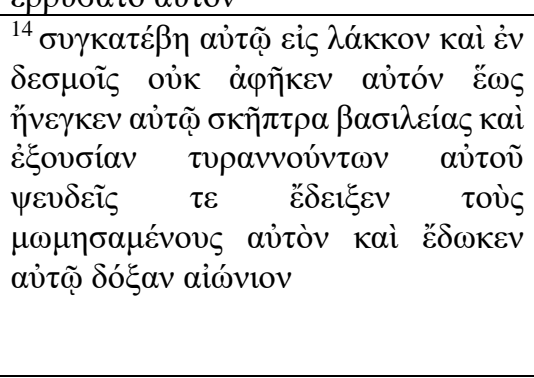 & $\begin{array}{l}{ }^{14} \text { she went down with him into the } \\
\text { dungeon, }{ }^{14)} \text { and when he was in } \\
\text { chains, she did not leave him until } \\
\text { she had brought him the scepter of } \\
\text { a kingdom and authority over those } \\
\text { who ruled over him. Those who had } \\
\text { found fault with him she showed to } \\
\text { be false and gave him everlasting } \\
\text { glory. }\end{array}$ & \\
\hline 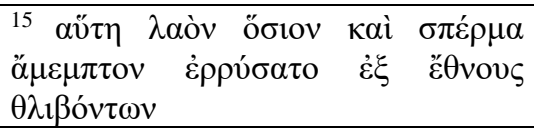 & $\begin{array}{l}15 \text { A holy people and a blameless } \\
\text { race she rescued from a nation of } \\
\text { oppressors; }\end{array}$ & \\
\hline 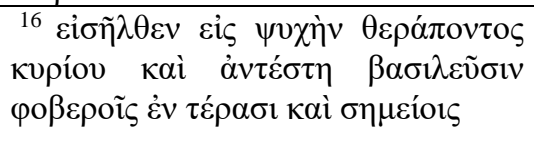 & $\begin{array}{l}16 \text { she entered into the soul of the } \\
\text { Lord's attendant and withstood } \\
\text { terrible kings with wonders and } \\
\text { signs. }\end{array}$ & \multirow{3}{*}{$\begin{array}{l}\text { Egypt } \\
\text { Move out of } \\
\text { Egypt } \\
\text { Red Sea }\end{array}$} \\
\hline 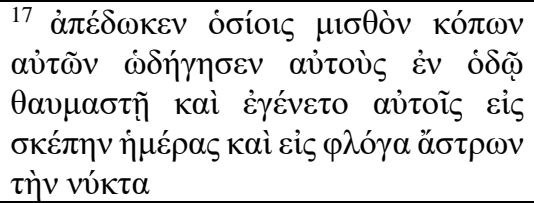 & $\begin{array}{l}{ }^{17} \text { She paid to holy people a reward } \\
\text { for their labors; she guided them on } \\
\text { a marvelous way and became a } \\
\text { covering for them by day and a } \\
\text { blaze of stars by night. }\end{array}$ & \\
\hline 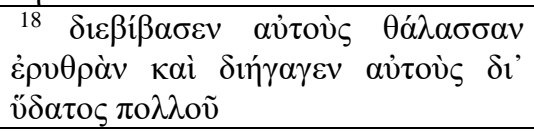 & $\begin{array}{l}{ }^{18} \text { She led them across the Red Sea } \\
\text { and brought them through deep } \\
\text { water, }\end{array}$ & \\
\hline
\end{tabular}




\begin{tabular}{|c|c|c|}
\hline 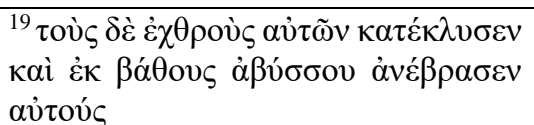 & $\begin{array}{l}19 \text { but their enemies she drowned, } \\
\text { and from the bottom of the deep she } \\
\text { cast them up. }\end{array}$ & \\
\hline 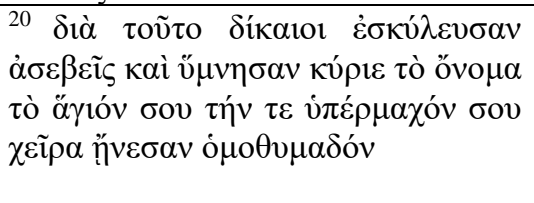 & $\begin{array}{l}20 \text { Therefore the righteous spoiled } \\
\text { the impious; they sang hymns, O } \\
\text { Lord, to your holy name and praised } \\
\text { with one accord your hand that } \\
\text { vindicated them, }\end{array}$ & \\
\hline 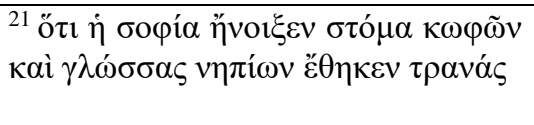 & $\begin{array}{l}21 \text { because wisdom opened the } \\
\text { mouth of the dumb and made the } \\
\text { tongues of infants articulate. }\end{array}$ & Moses \\
\hline
\end{tabular}

\begin{tabular}{|c|c|c|}
\hline \multicolumn{2}{|c|}{ Wisdom 11:1-4 } & \multirow{6}{*}{$\begin{array}{l}\text { Moses } \\
\text { Exodus }\end{array}$} \\
\hline $\mathbf{L X X} \mathbf{X}^{14}$ & $\begin{array}{l}\text { LXX NETS-Translation (Knibb } \\
\text { 2007, 706) }\end{array}$ & \\
\hline 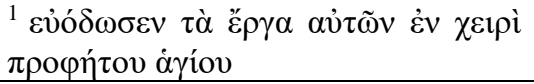 & $\begin{array}{l}{ }^{1} \text { She prospered their actions by the } \\
\text { hand of a holy prophet. }\end{array}$ & \\
\hline 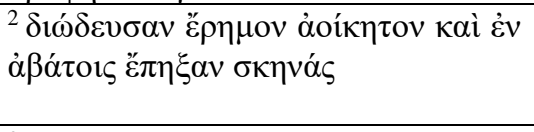 & $\begin{array}{l}2 \text { They journeyed through an } \\
\text { uninhabited wilderness and in } \\
\text { trackless places pitched their tents; }\end{array}$ & \\
\hline 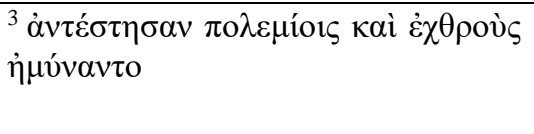 & $\begin{array}{l}{ }^{3} \text { they withstood their adversaries and } \\
\text { defended themselves against their } \\
\text { enemies. }\end{array}$ & \\
\hline 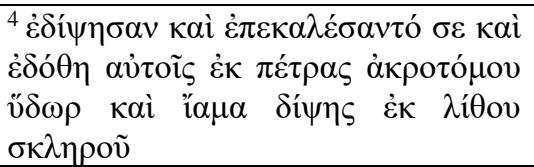 & $\begin{array}{l}{ }^{4} \text { They thirsted and called upon you, } \\
\text { and water was given them out of } \\
\text { flinty rock, and a remedy for their } \\
\text { thirst out of hard stone. }\end{array}$ & \\
\hline
\end{tabular}

Some scholars prefer to link Chapter 10 with the last part of the book because it introduces the retold historical interpretation that continues from Chapter 11 to Chapter 19, but the fact that the main subject in this chapter is wisdom (cf. Collins 1997, 180), lends it more towards a wisdom genre than a history genre. It also forms a very smooth transition to the next section. In Chapter 10, Sophia is the subject and the one guiding the forefathers. She is also mentioned in 11:1 and the story of Moses continues in Chapter 11, but from 11:4 God is the subject and the one saving and giving guidance, not Sophia.

It is clear that in Wisdom 10:1-11:1 a relationship with Sophia is promoted and this relationship is given as the reason the righteous characters in the Pentateuchal narratives prospered, were guided and protected. Those who did not follow her perished and were hindered from recognising what was good. Thus, the ones who abandoned her consequently made the wrong decisions. The righteous, who had a relationship with her, 
were guarded, delivered from transgression, given strength, guided, protected, kept strong and safe, rescued, shown a divine kingdom, got knowledge of the holy things, prospered, the fruit of their labour increased. They were favoured, not abandoned; they were accompanied by her in difficult times; they received glory; they could withstand terrible kings; in the day she was a cover for them and at night a blaze; she assisted him in his inadequacy; he prospered. Although the content of this text can be linked to the narratives in Genesis and the text can be intertextually compared with texts like Exodus 13-15, Deuteronomy 32, Joshua 24, Nehemiah 9, Psalms 78, 105, 106, 135 and 136, it is quite unique in content and outlook. The most noticeable difference is the fact that Sophia is the subject in Wisdom 10-11:1, while in the other texts it is YHWH.

Another outstanding aspect in this text is the universal attitude. This text is retelling the history without giving any names and without referring to a specific time or person. The persons' names are either replaced by "the righteous" or in the opposite case, by "the impious." This attitude can be linked to a few possibilities. One, it can be explained by the tendency of Judaic texts, especially second temple literature, to refer spontaneously to existing traditions and texts, without explicit referencing, and then the intertextual memories of the author as well as readers link the texts with each other. The second possible explanation is that it is part of the nature of Wisdom literature. In an attempt to be universally effective and not to be trapped in time and events, wisdom literature tends to apply universal approaches. This option will also embrace the nature of the Wisdom of Solomon as it is a text that is known for its strong individualistic, humanistic, and universalistic style (cf. Collins 1997, 230). The third possibility is that the author in his endeavour to synthesise Israelite and Hellenistic traditions ${ }^{15}$ attempted to bridge the gap between Jerusalem and Alexandria with a sort of anti-nationalism attitude. The reason for this universal approach is not clear; it can be any of the options mentioned or even all of them.

It became clear that the relationship with Sophia, where she is portrayed as the subject for the forefathers' guidance and protection, is quite unique of this text. In this text, the Pentateuchal narrative is linked to causality (cf. Schellenberg 2015, 124). Causality is a well-known attribute of wisdom literature and is most of the times called "retribution." What is interesting in this specific wisdom text is the fact that retribution is reinterpreted. In this case, the cause (just as in traditional wisdom) can be linked to a person's actions, but these actions are not on the level of doing, but on the level of a relationship. According to the Wisdom of Solomon, wisdom cannot be obtained by good deeds, it is a gift given by God (Wis 7:7; 8:4, 21, 9:4, 17). This is underlined by Wis

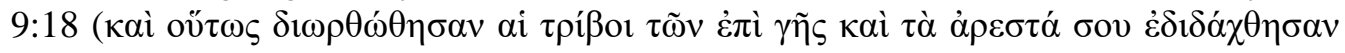

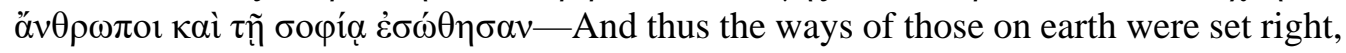
and human beings were taught what is pleasing to you and were saved by wisdom). This is the last verse in Wisdom 9, which is also a transitional verse to Chapter 10, which is

15 Refer to Baumann $(2014,70)$, Perdue $(2008,300)$, and Schaper (2013) for a discussion of this aspect. 
interwoven with this relationship. The Pentateuchal narrative is giving the reason for what happened to whom and this reason can be linked to the forefather's relationship with both Sophia and God.

\section{Development in the Concept of Wisdom and Retribution}

The intertwined love triangle and the causality as discussed above is also summarised in Wis 6:17-19:

${ }^{17}$ For her true beginning is the desire for instruction,

${ }^{18}$ and concern for instruction is love of her, ${ }^{(18)}$ and love of her is keeping her laws, and paying attention to her laws is confirmation of incorruption (immortality),

19 and incorruption (immortality) brings one near to God;

The term incorruption/aphtharsia is used three times in the Wisdom of Solomon (2:23; $6: 18 ; 6: 19$ ) and the corresponding adjective is used twice (Wis 12:1: ״̈ $\varphi \theta \alpha \rho \tau$ óv бov $\pi v \varepsilon \tilde{u} \mu \alpha$ - your incorruptible spirit, in 18:4 it refers to the "incorrupt light of the law"). According to Collins $(1997,186)$, this term had a technical meaning in Epicurean philosophy: "The Epicureans held that the gods had material existence, and they explained their unending life by saying that they were incorruptible." This term seems, therefore, to be understood in Wisdom of Solomon as "immortality." These verses can then be read to indicate that following Sophia confirms immortality, and immortality brings one near to God. If "incorruption" is understood as "immortality," then the succeeding verses in Wisdom 6 are in fact forming a parallelism with the previous ones:

${ }^{20}$ so the desire for wisdom leads to a kingdom. ${ }^{21}$ If therefore you take delight in thrones and scepters, you princes of peoples, honor wisdom that you may reign forever.

In a certain sense, this is underlining the message of the Wisdom of Solomon-the righteous pursue wisdom to obtain immortality and eventually a "kingdom". The Wisdom of Solomon's detachment from this life is radical (cf. Collins 1997, 182-91). This is also emphasised by Wis 8:13 and 17:

${ }^{13}$ Because of her, I will have immortality and will leave behind an everlasting memorial for those who come after me ... ${ }^{17}$ When I considered these things in myself and pondered in my heart that in kinship with wisdom is immortality.

\section{Concluding Remarks}

It seems that in the Wisdom of Solomon the love triangle between God, Sophia, and the righteous is portrayed as the only opportunity for immortality. This notion is motivated by linking the success of the forefathers to this relationship. In a certain sense, this text might be an attempt to overwrite the patriarchal tradition with a new tradition of a relationship with God, through Sophia. In the discussion on both the relational portrayal 
of Sophia and the retelling of the history in Wisdom of Solomon, it became clear that the concept of wisdom, as well as the concept of retribution, have gone through metamorphoses from the traditional perspective. ${ }^{16}$ Wisdom is no longer a skill that can be acquired, but it is a gift that can be prayed for and will be given by God. Wisdom is the mediator between God and the righteous and this relationship leads to immortality. Immortality is a notion that did not exist in earlier wisdom literature, it was first introduced by apocalyptic literature (cf. Collins 1997, 183-84). The Wisdom of Solomon is also the only Judaic wisdom book that does not emphasise "fear of YHWH" as important.

As an afterthought, it is interesting to notice how this concept of retribution through a relationship is further developed in the New Testament. In Hebrews 11 the Pentateuchal narrative is linked to belief, and in James 1:5, wisdom is also something that can be prayed for from God.

\section{References}

Baumann, Gerlinde. 1996. Die Weisheitsdestalt in Proverbien 1-9. Tubingen: Mohr (Paul Siebeck).

Baumann, Gerlinde. 2014. "Personified Wisdom: Contexts, Meanings, Theology."

In The Writings and Later Wisdom Books, edited by Christl M. Maier and Nuria Calduch-

Bengages, 57-75. Atlanta, GA: SBL Press. https://doi.org/10.2307/j.ctt1287n78.7

Bosman, Hendrik L. 2012. "The Theological Paraphrasing of History: The Exodus Tradition in the Wisdom of Solomon." HTS Teologiese Studies/Theological Studies, 68 (1): Art. \#1329: 7 pages. http:// dx.doi.org/10.4102/hts.v68i1.1329

Collins, John. J. 1997. Jewish Wisdom in the Hellenistic Age. Edinburgh: T\&T Clark.

Geyser-Fouché, Ananda B. 2019. "Lady Metaphors in Judaic Wisdom Literature.” In Scribal Practice, Text and Canon in the Dead Sea Scrolls, Essays in Memory of Peter W. Flint, edited by John J. Collins and Ananda Geyser-Fouché, 334-58, Leiden: Brill. https://doi.org/10.1163/9789004410732_019

Hayman, A. P. 1999. "The Survival of Mythology in the Wisdom of Solomon." Journal for the Study of Judaism 30: 125-39. https://doi.org/10.1163/157006399X00019

Kessler, John. 2013. Old Testament Theology. Divine Call and Human Response. Waco, TX: Baylor University Press.

16 I will not discuss the notion of "traditional wisdom" in depth; in this regard, refer inter alia to Loader (2014, 39-46), Collins (1997, 1-20, 224), Douglas (2015), and Kessler (2013, 447-506). 
Knibb, Michael A. 2007. "Wisdom of Solomon." In A New English Translation and the Other Greek Translations Traditionally Included under that Title of the Septuagint, edited by Albert Pietersma and Benjamin G. Wright, 697-714. Oxford: Oxford University Press.

Loader, James A. 2014. Proverbs 1-9. Leuven: Peeters.

Miller, Douglas. 2015. "Wisdom in the Canon: Discerning the Early Intuition." In Was There a Wisdom Tradition? New Prospects in Israelite Wisdom Studies, edited by Mark. R. Sneed, 87-144. Atlanta, GA: SBL Press. https://doi.org/10.2307/j.ctt173zmjp.8

Perdue, Leo G. 2008. The Sword and the Stylus: An Introduction to Wisdom in the Age of Empires. Grand Rapids, MI: Eerdmans Publishing Company.

Rahlfs, Alfred. 2006. Septuaginta Id est Vetus Testamentum graece iuxta LXX interpretes edidit Alfred Rahlfs (Editio altera quam recognovit et emendavit Robert Hanhart). Complete Text without Apparatus. Stuttgart: Deutsche Bibelgesellschaft.

Römer, Thomas C. 2013. "Yhwh, the Goddess and Evil: Is 'Monotheism' an Adequate Concept to Describe the Hebrew Bible's Discourses about the God of Israel?" Verbum et Ecclesia 34 (2): Art. \#841, 5 pages. http://dx.doi.org/10.4102/ve.v34i2.841

Schaper, Joachim. 2013. "NOMO $\Sigma$ and NOMOI in the Wisdom of Solomon." In The Reception of Torah in the Wisdom Literature of the Second Temple Period, edited by Bernd U. Schipper and D. Andrew Teeter, 293-306. Leiden: Brill. https://doi.org/10.1163/9789004257368_015

Schellenberg, Annette. 2015. "Don't Throw the Baby Out With the Bathwater: On the Distinctness of Sapiential Understanding of the World." In Was there a Wisdom Tradition? New Prospects in Israelite Wisdom Studies, edited by Mark R. Sneed, 115-44. Atlanta, GA: SBL Press. https://doi.org/10.2307/j.ctt173zmjp.9

Thom, Johan C. 2009. "Wisdom in the Wisdom Of Solomon and Cleanthes' Hymn to Zeus." In Septuagint and Reception, edited by Johann Cook, 195-207. Leiden: Brill. https://doi.org/10.1163/ej.9789004177253.i-414.60

Webster, Jane S. 1998. "Sophia: Engendering Wisdom in Proverbs, Ben Sira and the Wisdom of Solomon." Journal for the Study of Old Testament 78: 63-79. https://doi.org/10.1177/030908929802307804

Winston, David. 1979. The Wisdom of Solomon: A New Translation with Introduction and Commentary. The Anchor Bible. New York: Doubleday.

Zimmerman, Ruben. 2008. "The Love Triangle of Lady Wisdom: Sacred Marriage in Jewish Wisdom Literature.” In Sacred Marriages: The Divine-Human Sexual Metaphor from Sumer to Early Christianity, edited by Martti Nissinen and Risto Uro, 243-58. Winona Lake, IN: Eisenbrauns. https://doi.org/10.5325/j.ctv1bxgzv8.12 